\title{
SOME NEW HYMENOPTEROUS INSECTS FROM THE PHILIPPINE ISLANDS.
}

\author{
By S. A. Rohwer, \\ Of the Bureau of Entomology, Department of Agriculture, Washington, D. C.
}

The insects described below were, with the exception of Pseudagena chrysosoma, collected by Father Robert E. Brown, S. J., in the vicinity of Manila. From a brief study of the superfamilies Tenthredinoidea, Vespoidea, and Sphecoidea it seems that this fauna of the Philippine Islands, although related to, is distinct from the fauna of the neighboring mainland.

NESOSELANDRIA, new genus.

Small, habitus similar to the genera Aneugmenus Hartig and Caliroa. Clypeus small, subtruncate, with the lateral angles rounded; malar space wanting; eyes large, subparallel, lateral ocelli below superorbital line; postocellar area raised; pedicel cylindrical as long as scape, third antennal joint longer than fourth, but not as long as fourth and fifth combined; basitarsis as long as the following joints, apical joint long slender, as long as the second joint, the third and second joints somewhat flattened; tarsal claws with a large, erect, inner tooth; venation of the general type for Selandrinæ; third cubital much broader at the apex receiving the transverse radius beyond the middle; basal nervure strongly bent, as in some species of Stromboceros; transverse median its length from the apex of the first discoidal cell; hind radial cell not appendiculate; two hind discoidal cells; lanceolate cell shortly petiolate; sheath narrow; hypopygidium subquadrate at the apex rounded. The tarsi of male are more normal than in female. The first transverse cubitus in all the specimens before me is wanting, but this is a variable character.

Type-species.-Paraselandria imitatrix Ashmead.

Of the described genera this is most closely allied to Aneugmenus Hartig, but the absence of the pentagonal area, the longer pedicel, and the petiolate anal cell of the hind wings exclude it from that genus. 


\section{NESOSELANDRIA IMITATRIX Ashmead.}

Paraselandria imitatrix Ashmead, Proc. U. S. Nat. Mus., vol. 28, 1905, p. 971.

The following notes may aid in the determination of this species: Frontal crest strongly produced in the middle, slightly broken; a circular fovea above each antenna; an elongate transverse fovea in front of middle ocellus, but these are not strong; postocular furrows wanting, or nearly; antennæ hairy; stigma angled near middle.

MUTILLA (sens. lat.) BROWNI, new species.

Female.-Length about $6 \mathrm{~mm}$. Head slightly broader than the thorax; mandibles long and slender, with a tooth remote from the apex; antennal fovea large, shining, carinated above; head and thorax (including the posterior face) with large confluent punctures; thorax rectangular, constricted, and, when seen from above, dentate along the sides; pleuræ nearly smooth; lower part of the anterior face of first abdominal segment irregularly, confluently punctured, the upper part with fine striæ following around the margin; sculpture of the following segments hid by the dense pile; pygidium margined laterally, longitudinally striated, at the apex notched; legs normal. Head, legs, and abdomen black; thorax red; insect covered with loose, long hairs; the abdomen with close, dense, black pile; two lateral oval spots on the second segment and a broad band on the third dorsal segment white.

Type-locality.-Manila, Philippine Islands. Collected by Robt. Brown.

Type.-Cat. No. 12823, U.S.N.M.

Some of the paratypes are slightly smaller, but do not seem to differ otherwise.

The following species seem to form a group, but as the descriptions deal chiefly with color one can not feel certain. They may be separated as follows:

Third abdominal segment with the pale hair band reduced to lateral spots; (thorax

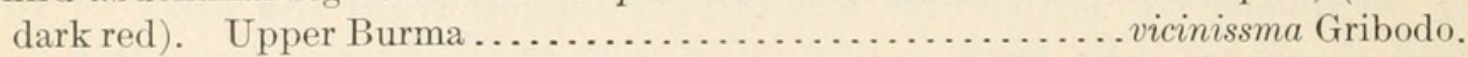
Third abdominal segment with a continuous pale hair band $\ldots \ldots \ldots \ldots \ldots \ldots \ldots . .1$ 1. Fifth abdominal segment with a pale hair band........... manillensis Brown. Fifth abdominal segment without a pale hair band ........... browni Rohwer.

PSEUDAGENIA CHRYSOSOMA, new species.

Female.-Length $11.5 \mathrm{~mm}$. Clypeus large, subconvex, anterior margin rounded; head finely granular; third antennal joint almost as long as four and five combined; scutel more than half as long as dorsulum; area behind postscutel rather strongly transversely wrinkled, area at the sides of the postscutel obliquely wrinkled; legs feebly spined; pygidial area very finely granular; on cubitus the second and third cubital cells are subequal; transverse median a little more than its length beyond the basal. Black: mandibles, an- 
tennæ, and legs entirely yellowish-ferruginous; body, except venter and most of pleuræ and the area behind and at the sides of postscutel, very densely clothed with bright golden pile. Wings to the stigma yellowish hyaline, below stigma is a transverse infuscate band, the apex subhyaline; venation yellowish or yellowish-brown.

Type-locality.-Grand Malindang Mountain, North Mindanao, Philippine Islands, June 3-8, 1906 . Collected by Dr. E. A. Mearns, U. S. Army.

Type.-Cat. No. 12822, U.S.N.M.

This beautiful species may not belong to Pseudagenia, but it agrees with the characters of that genus better than any other known to the author, and until the genera are revised had best be left there.

DOLICHURUS STANTONI (Ashmead).

Thyreosphex Ashmead=Dolichurus Latrenle.

This remarkable little wasp was described as a new genus, Thyreosphex, ${ }^{a}$ by Dr. W. H. Ashmead and placed in the Larridæ, but it has nothing to do with that family, and there can be no doubt that Thyreosphex is the same as Dolichurus. The female of this species agrees in general with the male.

\section{NOTOGONIA CRAWFORDI, new species.}

Female.-Length $14 \mathrm{~mm}$. Anterior margin of the clypeus rounded, without teeth, slightly notched; head closely, finely punctured; scape carinated ventrally; eyes at the vertex separated by about the length of second and third antennal joints; third and fourth antennal joints subequal; dorsulum and scutel finely, closely punctured; scutel not impressed; metanotum granular; pygidium at apex with a V-shaped notch. Black: tegulæ brownish; the usual silvery pubescence; pygidium with brownish pubescence. Wings hyaline, with a strong yellow tinge; venation reddish-yellow.

Type-locality.-Manila, Philippine Islands. Collected by R. E. Brown.

Type.-Cat. No. 12820, U.S.N.M.

Perhaps closest to $N$. jaculatrix (Smith), but distinct in the finely granular metapleuræ.

Named for Mr. J. C. Crawford, who had first determined it as new.

NOTOGONIA MANILENSIS, new species.

Male.-Length about $9 \mathrm{~mm}$. Anterior margin of clypeus subtruncate, slightly notched in the middle; head, dorsulum, and scutel finely, closely punctured; scape carinated ventrally; antennal joints rounded out beneath; third and fourth joints subequal; scutel not impressed; metanotum with distinct, slightly oblique striæ, which 
extend on to the upper part of the pleuræ; posterior face with transverse striæ, the longitudinal furrow deep, narrow; longer spur of hind tibiæ equal in length with basitarsis; last ventral segment with a U-shaped notch, the lobes broad rounded. Black: tegulæ brownish; wings fusco-hyaline; venation dark brown.

Type-locality.-Manila, Philippine Islands. Collected by R. E. Brown.

Type.-Cat. No. 12821, U.S.N.M.

This may be the male of crawfordi, but the following differences seem more than sexual: Legs weakly spined, longer spur of hind tibiæ equal to basitarsis, striæ of metanotum, and much darker wings.

PSENULUS (NEOFOXIA) XANTHOGNATHUS, new species.

Male.-Length about $6.5 \mathrm{~mm}$. Anterior margin of the clypeus simple; a rectangular area bounded by carinæ below the antennæ; eyes strongly converging toward the clypeus; antennæ submoniliform; head shining, with distinct separate punctures; dorsulum punctured like the head, but duller; scutel and mesopleuræ shining almost impunctate; metathorax, except the finely granular pleuræ, strongly reticulate; petiole simple, longer than the hind femora. Black: mandibles, palpi, scape, pronotum, tubercles, scutels, four anterior legs below the trochanters, hind tibiæ except apices, and hind tarsi bright yellow; tegulæ brownish, wings hyaline, beautifully iridescent; venation dark brown.

One paratype, which has its cocoon on the pin, has the markings whitish, but was probably killed before it had time to harden.

Type-locality.-Manila, Philippine Islands. Collected by R. E. Brown.

Type.-Cat. No. 12819, U.S.N.M.

This species was recorded as Psen algii Ashmead in Brown's catalogue of Philippine Hymenoptera, ${ }^{a}$ but this is a misspelled manuscript name, which has not been adopted. 


\section{$2 \mathrm{BHL}$ Biodiversity Heritage Library}

Rohwer, S. A. 1910. "Some new hymenopterous insects from the Philippine Islands." Proceedings of the United States National Museum 37(1722), 657-660. https://doi.org/10.5479/si.00963801.1722.657.

View This Item Online: $\underline{\text { https://www.biodiversitylibrary.org/item/53183 }}$

DOI: https://doi.org/10.5479/si.00963801.1722.657

Permalink: https://www.biodiversitylibrary.org/partpdf/51148

\section{Holding Institution}

Smithsonian Libraries

\section{Sponsored by}

Smithsonian

\section{Copyright \& Reuse}

Copyright Status: NOT_IN_COPYRIGHT

This document was created from content at the Biodiversity Heritage Library, the world's largest open access digital library for biodiversity literature and archives. Visit BHL at https://www.biodiversitylibrary.org. 